\title{
Qualitative Analysis of Extent and Severity of Desertification for Semi-Arid Regions Using Remote Sensing Techniques
}

\author{
M. V. Khire and Y. Y. Agarwadkar
}

\begin{abstract}
International Convention to Combat Desertification (CCD) defines desertification as "land degradation in arid, semi-arid and dry sub-humid areas resulting from various factors, including climate variations and human activities". Desertification is a self-accelerating process, with exponentially rising rehabilitation costs. Biophysical, climatological and socio-economical parameters need to be integrated for analysis. Remote sensing is an effective monitoring technique due to temporal and synoptic data.

Current work aims at integrating various parameters influencing desertification process for estimation of qualitative desertification severity using GIS. Proposed method uses satellite data as basic input along with climatic, terrain and demographic data. Weightage-driven approach is used for evaluating desertification severity map using regression analysis using field data. Remote sensing based indicators have high weightages as compared to ancillary data. The areas under medium to high severity classes are stressing the need of continuous monitoring and mitigation measures.
\end{abstract}

Index Terms-Desertification, regression analysis, remote sensing and GIS, severity index, weightage driven approach.

\section{NEED OF DESERTIFICATION MAPPING}

International Convention to Combat Desertification (CCD) adopted by United Nations [1], defines desertification as "land degradation in arid, semi-arid and dry sub-humid areas resulting from various factors, including climate variations and human activities". The anthropologic processes like unplanned developments, human and livestock population pressure, industrialisation, urbanisation and mining may speed up the desertification process. Around $90 \%$ of two billion people dependent on ecosystems in dry lands live in developing countries. Overpopulation causes overexploitation of land resources in dry lands [2]. Human population pressure is most crucial indicator for desertification in a country like India [3]. In India 32.75 percent of the total geographical area is affected by various forms and degree of desertification [4], [5]. The adversely changing rainfall pattern and rising trends in temperature are making this desertification scenario more severe.

Agriculture is the backbone of Indian economy which in turn is mainly dependant on monsoon. The variation and the

Manuscript received August 20, 2013; revised October 24, 2013, this work was supported by MoEF, GOI by sponsoring project titled "An Integrated Technique for Monitoring Desertification Using Intelligent GIS ".

Khire M. V. and Agarwadkar Y. Y. are with the Centre of Studies in Resources Engineering, Indian institute of Technology Bombay, Powai, Mumbai, India $400076 \quad$ (e-mail: mvk@csre.iitb.ac.in; yogesh.y.y.a@gmail.com). distribution of rainfall is not uniform throughout India. The country passed through a severe drought phase during mid-nineties; the effects of which were extended till early millennial years. This phase affected almost 12 states of India - especially Maharashtra, Gujarat, Rajasthan, Madhya Pradesh and Andhra Pradesh - close to 100 million people and 3.4 million cattle were caught in the grip of drought [4]. Eastern and central Maharashtra State, India is a severely drought prone area [6]. Identification of these susceptible areas at district / sub-district level and their severity on regular basis is necessary for curbing effects of desertification and efficient planning.

Desertification is a self-accelerating process, feeding on itself and rehabilitation costs rise drastically. Preventive and rehabilitation measures needs to be taken urgently before the cost for rehabilitation increases beyond feasible resources or before the opportunity to act is lost forever [7].

Desertification is considered to be a consequence of a complex mix of hidden and apparent reasons out of which drought is considered as most complex and least understood cause [8], [9]. Being an assembled process of associated activities, desertification brings variations in a particular ecosystem and increases the susceptibility of marginally dry land [10]. Dry lands are under severe pressure from both human activities and severe climatic conditions and need better management practices for conservation of ecosystem [11]. The process of desertification may aggravate temporally due to drought, climate variability, climate change, soil erosion, salinity, water logging, population pressure, human fallibility and resources exploitation [12]. Vulnerability of land towards desertification depends on the interactions of natural and human-derived factors [13]. Desertification describes circumstances of land degradation in arid, semi-arid and dry sub-humid ecosystems resulting from the climatic and human activities [14].

\section{Remote Sensing As ToOl for Desertification ANALYSIS}

Satellite remote sensing is one of the best techniques for monitoring desertification due to synoptic coverage and temporal nature. The Ottichilo report on "Use of space technology in disaster risk assessment and monitoring" [15] emphasises that the mitigation of the effects of disasters requires relevant information regarding the disaster in real time. Disasters like desertification cause huge social and economic disruptions and normally affect large areas or territories. Direct economic losses are reductions in income 
obtained as a result of the lower productivity [16]. These 'on-site' costs are experienced either by the land user who degraded the land or another user who uses the site subsequently. They are linked to global change and it is not possible to effectively collect continuous data on them using conventional methods. Monitoring and assessment involves acquisition of information through field surveys, available records, and remote sensing [17], [18].The space technology or remote sensing tools offer excellent possibilities of collecting this vital data. This is because the technology has capability of collecting data at global and regional scales rapidly and repetitively and the data is collected in digital form.

Costantini et al. [19] have studied the risk of desertification in Italy at continental, national and regional level. This study was aimed at creating a new atlas of risk of desertification in Italy. The methodology was based on the use of indicators. They combined different climatic, vegetation, soil attributes with socio-economic attributes to estimate pressure on land and state of soil and vegetation multiplicatively.

Desertification is a global environmental problem [20], [21]. Accurate assessment of the changes in status and trend of desertification will be instrumental in developing global actions to prevent and eradicate the problem [22].

\section{PARAMETERS CONSIDERED FOR DESERTIFICATION ANALYSIS}

Various parameters considered in this study are enlisted in Table I:

TABLE I: PARAMETERS CONSIDERED

\begin{tabular}{|c|c|}
\hline \multirow{2}{*}{$\begin{array}{c}\text { Biophysical } \\
\text { parameters }\end{array}$} & Land use / land cover (LU/LC) changes \\
\cline { 2 - 2 } & Various vegetation indices \\
\cline { 2 - 2 } & Erosion due to rainfall and wind \\
\hline \multirow{2}{*}{$\begin{array}{c}\text { Socio-economic } \\
\text { parameters }\end{array}$} & Population pressure index \\
\cline { 2 - 2 } & Livestock pressure index \\
\hline Climatic parameters & Meteorological drought \\
\cline { 2 - 2 } & Aridity index \\
\hline \multirow{2}{*}{$\begin{array}{c}\text { Surface \& Ground } \\
\text { water Parameters }\end{array}$} & Surface \& ground water depletion \\
\cline { 2 - 2 } & Surface \& ground water quality changes \\
\hline
\end{tabular}

\section{STUDY AREA}

Aurangabad is a district in central India. Spatial extent of Aurangabad district is ranging from latitude $74^{0} 35^{\prime} \mathrm{E}$ to $75^{\circ} 55^{\prime} \mathrm{E}$ and longitude $19^{\circ} 20^{\prime} \mathrm{N}$ to $20^{\circ} 40^{\prime} \mathrm{N}$, the location of the district is given in Fig. 1.

It lies in semiarid zone as per the Agro-climatic Atlas of India. The area has extreme summers with temperatures reaching up to $45-47^{0} \mathrm{C}$. Average annual rainfall measures in the range of $900-1000 \mathrm{~mm}, 80 \%$ of it is during the monsoon. In recent times, due to climatic changes, the rainfall has become aberrant and the monsoon is not uniformly distributed in this area. December is the coldest month and May is the hottest month. The relative humidity varies between $65 \%$ and $75 \%$ during wet season and between $30 \%$ and $40 \%$ during the rest of the year. The climate of the area is normally dry throughout the year, except a very short spell of wet South-West monsoon between July and September. The annual average sunshine hour is more than 8 hours/day. In April it stretches up to 10 hours. In monsoon days it reduces to 3-4 hours. The seasonal variation in soil temperature is $17^{\circ} \mathrm{C}$ to $45^{\circ} \mathrm{C}$ at $5 \mathrm{~cm}$. depth. The rate of evaporation is high over the area. Annual rate of evaporation is $300-350 \mathrm{~cm} \mathrm{[23],}$ [24].

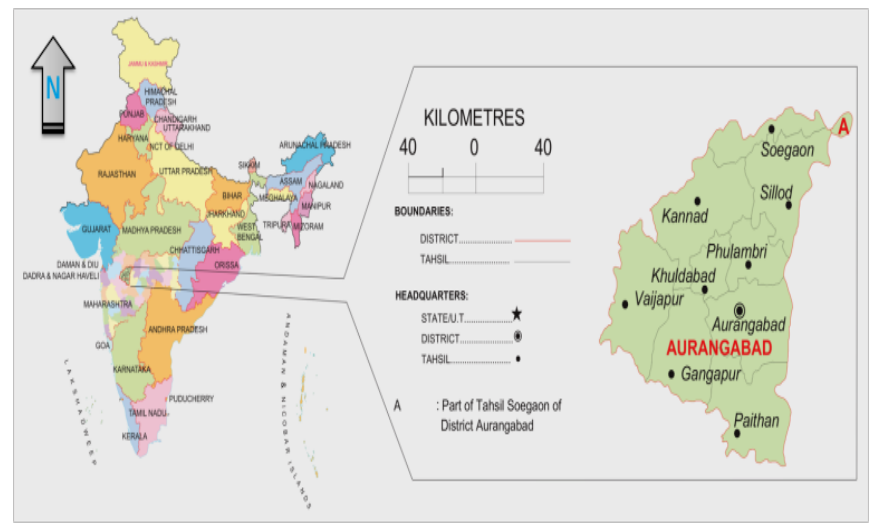

Fig. 1. Location of study area in India (source: Census of India, 2011).

The major part of Aurangabad is covered with basaltic rock. The massive basalt is a dark grey to black rock having fine to medium fine texture. It has resulted in the present landscape of very large stony wastes in the south with lots of intermittent rock outcrops. In the north at some locations laterite ridges are followed by huge traps. The overall slope of terrain is North-West to South-East. The terrain is steeply sloped in North-West whereas gently sloped in South-East. The study area has an elevation range between 300-900 m from mean sea level [25].

\section{DESERTIFICATION ANALYSIS}

Satellite data used for this study is Indian Remote Sensing data of pre-monsoon season for years 1989 and 2010 for which census data of year 1991 and 2001 is available from Census of India. For elevation information Shuttle Radar Topography Mission (SRTM) data and Advanced Spaceborne Thermal Emission and Reflection Radiometer (ASTER) Global Digital Elevation Model (GDEM) is used. Details of satellite data are provided in Table II. The soil related data used is collected from National Bureau of Soil Survey and Land Use Planning (NBSS-LUP). Rainfall and temperature data is collected as high resolution gridded data from Indian Meteorological Department (IMD), Pune. Due to unavailability of livestock data for the current work this parameter has not been used. The LU/LC maps are generated using IRS imagery. The images are classified using supervised classification. The flow chart for methodology used for current work is given in Fig. 2. 


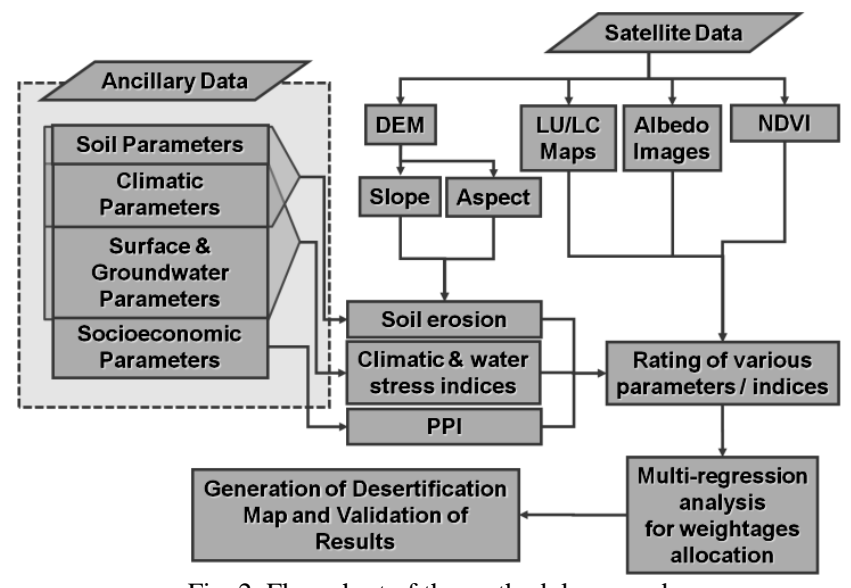

Fig. 2. Flow chart of the methodology used.

\begin{tabular}{|c|c|c|c|}
\hline \multirow[t]{2}{*}{ IRS data } & LISS I $^{1}$ & $72.5 \mathrm{~m}$ resolution & $3^{\text {rd }}$ March 1989 \\
\hline & $\mathrm{AWiFS}^{2}$ & $56 \mathrm{~m}$ resolution & $5^{\text {th }}$ February 2010 \\
\hline \multirow[t]{2}{*}{ Elevation data } & SRTM data & $90 \mathrm{~m}$ resolution & February 2000 \\
\hline & ASTER GDEM & $30 \mathrm{~m}$ resolution & October 2011 \\
\hline
\end{tabular}

\section{A. Vegetation Index}

Normalised Differential Vegetation Index (NDVI) is calculated as a ratio between measured reflectivity in the red and near infrared $(N I R)$ portions of the electromagnetic spectrum (Eq. (1)). These two spectral bands are chosen because they are most affected by the absorption of chlorophyll in leafy green vegetation and by the density of green vegetation on the surface. The contrast for vegetation is maximum in red and NIR bands [26].

$$
N D V I=\frac{N I R-R \mathrm{e} d}{N I R+R \mathrm{e} d}
$$

where NIR

near infrared band

Red

Red band

\section{B. Albedo}

Albedo is generally defined as the instantaneous ratio of surface-reflected radiation flux to incident radiation flux over the shortwave spectral domain. It is a dimensionless parameter [27].

Otterman [28] showed that overgrazing in desert regions can increase surface albedo by as much as $20 \%$. Charney [29] estimated that such changes may suppress rainfall, which would enhance the process of desertification that is occurring in sub-Saharan Africa. Sagan et al. [30] proposed that extensive deforestation in tropical rainforests may significantly increase surface albedo and result in major climate changes. Fernández et al. used albedo as an important indicator for climatic and biophysical consequences [31]. Robinove et al. [32] and Tueller [33] described a methodology based on Landsat Albedo of earth surface in the wavelength range of $0.5 \mu \mathrm{m}-1.1 \mu \mathrm{m}$.

\section{Soil Erosion}

Soil erosion due to rainfall is calculated using USLE model

\footnotetext{
${ }^{1}$ Linear Imaging Self Scanning Sensor I

${ }^{2}$ Advanced Wide Field Sensor
}

given by Wischmeier and Smith [34], [35]. This equation to estimated soil loss is given in Eq. (2) works with British units.

$$
U=R \times K \times L S \times C \times P
$$

Details of the parameters used in Eq. (2) are given below along with method followed for estimation of these parameters.

\section{1) Rainfall erosivity factor $(R)$}

$R$ has been calculated using Fournier's index, $p^{2} / P$, developed by Arnoldus [36], [37], which uses average monthly $(p)$ and annual precipitation $(P)$. The relationship (in metric units) (given in Eq. (3))

$$
R=1.735 \times 10^{1.5 \times \log \left(\sum \frac{p^{2}}{P}-0.8188\right)}
$$

has been summed for each of the 12 months of each year.

\section{2) Soil erodibility factor $(K)$}

$K$ factor defines the resistance of the soil to both detachment and transport. The spatial variation of the $K$ factor is determined using charts and soil maps prepared by NBSS-LUP.

\section{3) Length slope (LS) factor}

$L S$ factor is calculated using Wischmeier and Smith method given in Eq. (4) [34]:

$$
\begin{aligned}
& L S=\left(\frac{L}{22.1}\right)^{m} \times\left(65.41 \times \sin ^{2} \phi+4.56 \times \sin \phi\right. \\
& +0.065)
\end{aligned}
$$

where

$$
\begin{aligned}
& L \text { cumulative slope length (feet); } \\
& \phi \text { downhill slope angle; } \\
& m \text { is a slope contingent variable; } \\
& 0.5 \text { if the slope is more than } 2.86^{\circ}, \\
& 0.4 \text { on slopes of } 1.72^{\circ} \text { to } 2.86^{\circ} ; \\
& 0.3 \text { on slopes of } 0.57^{\circ} \text { to } 1.72^{\circ} ; \\
& 0.2 \text { on slopes less than } 0.57^{\circ}
\end{aligned}
$$

\section{4) Land cover management factor $(C)$}

As per Liu et al. land cover management factor can be defined as the ratio of soil losses of the same size soils under two different managements, that is one under some certain cover and management measures, the other under continuous clean tillage [38]. Van der Knijff et al. [39] gave equation for $\mathrm{C}$ based on NDVI given in Eq. (5).

$$
C=1-e^{\left(\frac{2.5 \times N D V I}{1-N D V I}\right)}
$$

\section{5) Support practice factor $(P)$}

$P$ varies from 0.5 to 1 depending on slope. As the values of 
this parameter are not well defined and not known for entire area it is assumed to be uniform in the study area as one.

For wind erosion (WE), due to lack of detailed wind related data, a qualitative approach is used based on prevalent wind speed and duration information in combination of slope aspect maps.

\section{Other Parameters}

Digital Terrain Model (DTM) is generated using SRTM and ASTER GDEM data. Further using this DTM, slope and aspect maps are generated.

Rainfall and Temperature data is used for analysis of De Martonne's Aridity Index (DMAI) [40], [41] and meteorological drought (MD) recurrence index described by Tiwari et al. [42].

Population pressure on land resources is calculated based on Population Pressure Index as function of population density based on Eq. (6),

$$
P P I=\frac{(P i-P)}{P}
$$

where $P$ is average population density

$P i$ is population density of final year.

Various parameters mainly LU/LC, albedo and vegetation index can be used as indicators for desertification if mapped temporally. To understand these temporal variations temporal difference of these parameters, i.e. differential parameters are used. Later date parameter values are subtracted from prior date values to get these differential images. The products derived using LISS I data of resolution $72.5 \mathrm{~m}$ are re-sampled to resolution of AWiFS data, i.e. $56 \mathrm{~m}$, using nearest neighbourhood method prior to calculation of differential layers. No correction is needed for season of satellite data as both images are of the pre-monsoon season with no climatic variability.

\section{E. Defining Weightages Using Multiple Regression}

Values of weightages are estimated by multiple regression analysis of field data collected from the study area. For this purpose generalised least square multiple regression analysis is used for solving the equation for calculation of weightages using training data collected from study area. As some of the parameters used are not mutually exclusive and are correlated with each other; generalised least square regression method is used. All the parameters are used simultaneously for regression analysis, i.e., standard multiple regression model is used for identification weightages. Total 157 sample points are used for regression analysis. The sample to variable ratio is over $17: 1$. This is more than the minimum sample size of $5: 1$ and within the range of commonly required acceptable sample size range of $15: 1$ to $20: 1$. This also satisfies the minimum sample size prescribed by Green [43] given by Eq. (7).

$$
N=50+8 \times k
$$

where,

$N$ minimum sample size

$k$ number of predictors

\section{F. Desertification Analysis}

The values of differential parameters (LU/LC, albedo and vegetation index) and other parameters (soil loss, meteorological drought, aridity index, population pressure index) are then further generalised by grouping into five severity classes based on their influence on desertification. These classes are given values from one to five as the increasing severity values, one being least severe to five being very severe. Finally these all parameters are integrated by weighted summation to calculate severity of desertification process based on Eq. (8).

$$
S=\sum\left(W_{X} \times I_{X}\right)
$$

$W_{X} \quad$ weightage for specific parameter $X$

$I_{X}$ Rating for key parameter $X$

The values calculated using Eq. (9) is then grouped in into 5 classes. The classes are mainly based linear grouping of $S$ (details given in Table III).

TABLE III: TABLE FOR GROUPING $S$ VALUES

\begin{tabular}{|c|c|}
\hline range of $S$ & Class \\
\hline $100-150$ & No Desertification \\
\hline $150-250$ & Mild Desertification \\
\hline $250-350$ & Moderate Desertification \\
\hline $350-450$ & Severe Desertification \\
\hline $450-500$ & Very Severe Desertification \\
\hline
\end{tabular}

\section{RESULTS AND DISCUSSIONS}

The multiple regression analysis for weightages gives following equation for desertification severity analysis. The $\mathrm{R}$-square value (i.e. coefficient of determination) is 0.61 . The coefficient of variation is 0.78 , as per Noble [44] the coefficient of variation in the range of 0.6 to 0.9 is considered to be good and indicating strong relationship. The individual parameters calculated are integrated using weighted sum method (as per Eq. (9)).

$$
\begin{aligned}
& \text { Desertification Severity }=17.5 \times N D V I+16.2 \times \\
& \text { LULC }+13.7 \times \text { Albedo }+13.5 \times U S L E+10.5 \times \\
& \text { Meteorological Drought }+9.2 \times \text { Wind Erosion } \\
& +9.1 \times \text { DMAI }+6.2 \times \text { Ground Water Depletion } \\
& +4.1 \times P P I
\end{aligned}
$$

The equation suggests that desertification phenomenon is more sensitive towards albedo change followed by LU/LC change and USLE; whereas population pressure has least contribution in current study.

The Fig. 3 shows desertification severity map of the Aurangabad district based on Eq. (9). The south-western part of the study area is falling in lower severity values as compared to the north part of the area. This could be due to presence of rivers in south-western part of the study area. 


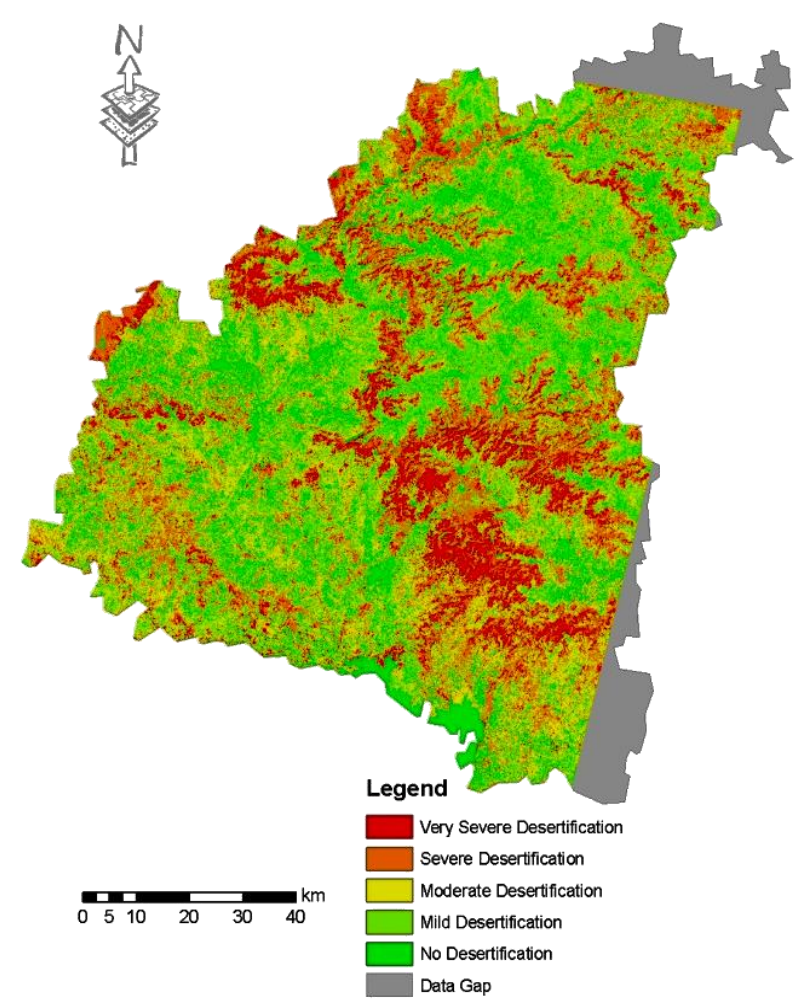

Fig. 3. Desertification severity map for Aurangabad District.

The area statistics given in Table IV indicate that this area shows mild to moderate desertification severity as a whole.

TABLE IV: AREA UNDER VARIOUS SEVERITY CLASSES

\begin{tabular}{|c|c|}
\hline Severity Class & Area \% \\
\hline Very Severe Desertification & 1.04 \\
\hline Severe Desertification & 21.21 \\
\hline Moderate Desertification & 32.14 \\
\hline Mild Desertification & 26.31 \\
\hline No Desertification & 19.3 \\
\hline
\end{tabular}

\section{CONCLUSIONS}

Weightages derived using regression analysis are in the same range as that of the previous studies done for Aurangabad District with an exception of population pressure index.. Population pressure index has got less weightage in the current analysis due to its lower spatial resolution (i.e. one value for one sub-district). The parameters like NDVI, albedo and land use land cover dynamics has got higher weightages as anticipated from literature and prior studies.

The desertification analysis of the Aurangabad District indicates that more than half of the area in the district is above mild desertification level. The rainfall patterns are changing in this area i.e., variations from the mean has increased since 1970. Along with this erratic rainfall, increases in monthly lowest temperature are the parameters which will increase the severity of desertification. Hence, timely intervention and mitigation measures need to be taken for the study area, specially the severe and moderate desertified area.

The methodology can be improved using higher resolution satellite remote sensing data. The coefficient of variation can further be improved with the help of uncertainty analysis of field data samples.

\section{ACKNOWLEDGMENT}

Authors would like to thank Ministry of Environment and Forests, Government of India for funding the current work. They would also like to express their gratitude towards Indian Institute of Technology, Bombay for support and their infrastructure.

\section{REFERENCES}

[1] United Nations, Elaboration of an international convention to combat desertification in countries experiencing serious drought and / or desertification, particularly in Africa, United Nations General Assembly, New York, 1994, res. 49/234, 49 U.N. GAOR Supp. (No. 49) at 155, U.N. Doc. A/49/49 (1994).

[2] United Nations Convention to Combat Desertification, Desertification: A Visual Synthesis, Y. Hori, C. Stuhlberger, and O. Simonett, Eds. UNCCD Publications, 2011.

[3] Ministry of Environment and Forests: Government of India, Status of Desertification, Nation action programme to combat desertification, in the context of United Nations convention to combat desertification (UNCCD), Government of India, New Delhi, India, 2001, vol. 1, pp. 1-27.

[4] Ministry of Environment and Forests: Government of India, 3rd National Report on Implementation of United Nations Convention to Combat Desertification, Submitted to United Nations Convention to Combat Desertification (UNCCD) Secretariat, Bonn, Germany 2006, Government of India: New Delhi, India, pp. 1-59.

[5] Ministry of Environment and Forest, Press Release: Nation Celebrates Today World Day to Combat Desertification, Press Information Bureau, Government of India, New Delhi, 2008.

[6] Government of Maharashtra, Meeting on Development of Irrigation Potential and Drought Mitigation Measures in Maharashtra, Government of Maharashtra, New Delhi, 2013, pp. 1-25.

[7] P. Reining, "Handbook on Desertification Indicators: Based on the Science Associations Nairobi Seminar on Desertification," American Association for the Advancement of Science, Washington, D.C., 1978, vol. xviii, pp. 141.

[8] A. Warren and J. K. Maizels, "Ecological change and desertification," in Proc. Secretariat of United Nations Conference on Desertification: Its Causes and Consequences, Oxford: Pergamon Press, 1977.

[9] UNESCO Chair of Eremology and Belgian Development Cooperation, in Combating Desertification: Monitoring, Adaptation and Restoration Strategies, D. Gabriels, W. M. Cornelis, M. Eyeletters and P. Hollebosch, Eds., UNESCO Chair of Eremology and Belgian Development Cooperation, Belgium, 2008.

[10] Indian Council of Agricultural Reseach, Central Arid Zone Reseach Institute, Progress in Arid Zone research 1952-1987, presented at Firs Consultative Meeting of the Regional Network of Research and Training Courses on Desertification Control in Asia, Government of India, 1988.

[11] J. Evans and R. Geerken, "Discrimination between climate and human-induced dry land degradation," Journal of Arid Environments, vol. 57, issue 4, pp. 535-554, 2004.

[12] C. J. Barrow, Land Degradation: Development and Breakdown of Terrestrial Environments, 1st ed. UK: Cambridge University Press, 1991.

[13] L. Salvati, "A socioeconomic profile of vulnerable land to desertification in Italy," Science of the Total Environment, vol. 466-467, pp. 287-299, January 2014.

[14] M. M. Elhag, "Causes and impact of desertification in the Butana area of Sudan," Ph.D. dissertation, Dept. of Soil, Crop and Climate Sciences, University of the Free State, Bloemfontein, 2006.

[15] W. K. Ottichilo, "Use of space technology in disaster risk assessment and monitoring," in Proc. Second International Conference on Early Warning (EWC-II), Bonn, Germany, 2003.

[16] United Nations Convention to Combat Desertification, "Economic and social impacts of desertification, land degradation and drought," White Paper I: UNCCD 2nd Scientific Conference, Bonn, Germany, P. S. Low, Ed. The Global Risk Forum GRF Davos and UNCCD, Germany, 2013.

[17] J. E. M. Baartman, G. W. J. van Lunden, M. S. Reed, C. J. Ritsema, and R. Hessel, "Desertification and land degradation: origins, processes and solutions," Desire Report Series, ISRIC, Netherlands, no. 4, November 2007.

[18] J. V. Vogt, U. Safriel, G. V. Maltitz, Y. Sokona, R. Zougmore, G. Bastin, and J. Hill, "Monitoring and assessment of land degradation and desertification: towards new conceptual and integrated 
approaches," Land Degradation and Development, vol. 22, pp. 150-165, March/April 2011.

[19] E. A. C. Costantini, M. Bocci, G. L' Abate, A. Fais, G. Leone, G. Loj, S. Magini, R. Napoli, P. Nino, and F. Urbano, "Mapping the state and risk of desertification in Italy by means of remote sensing, soil gis and the EPIC model: methodology validation in the Sardinia island, Italy," in Proc. International Symposium: Evaluation and Monitoring of Desertification, Synthetic Activities for the Contribution to UNCCD, Tsukuba, Ibaraki, Japan: NIES publication, 2004.

[20] L. C. Stringer, "Reviewing the international year of deserts and desertification 2006: what contribution towards combating global desertification and implementing the United Nations Convention to Combat Desertification?" Journal of Arid Environments, vol. 72, issue 11, pp. 2065-2074, November 2008.

[21] P. D' Odorico, A. Bhattachan, K. F. Davis, S. Ravi, and C. W. Runyan, "Global desertification: drivers and feedbacks," Advances in Water Resources, vol. 51, pp. 326-344, January 2013.

[22] X. Yang, K. Zhang, B. Jia, and L. Ci., "Desertification assessment in China: an overview," Journal of Arid Environments, vol. 63, issue 2, pp. 517-531, October 2005.

[23] The Gazetteer Department, Climate of Aurangabad, Gazetteers Department, Government of Maharashtra, Mumbai, 2006.

[24] A. Z. Parishad, "Vision Aurangabad 2020," Water, NIC, Aurangabad, ch. 7, pp. 101-124, 2010

[25] The Gazetteer Department, Physical Geography, Geology and Meteorology of Aurangabad, Gazetteers Department, Government of Maharashtra, Mumbai, 2006

[26] M. Bindi, G. Brandani, A. Dessì, C. Dibari, R. Ferrise, M. Moriondo, and G. Trombi, Impact of Climate Change on Agricultural and Natural Ecosystems, Firenze University Press, 2009, pp. 217.

[27] C. B. Schaaf, "Albedo: Albedo and reflectance anisotropy," in Assessment of The Status of The Development of The Standards for The Terrestrial Essential Climate Variables, Global Terrestrial Observing System, NRC of Food and Agriculture Organization of the United Nations (FAO), Rome, 2009.

[28] J. Otterman, "Anthropogenic impact on the albedo of the earth," Climatic Change, vol. 1, issue 2, pp. 137-155, 1977.

[29] J. G. Charney, "Dynamics of deserts and drought in the Sahel," Quarterly Journal of the Royal Meteorological Society, vol. 101, issue 428, pp. 193-202, April 1975.

[30] C. Sagan, O. B. Toon, and J. B. Pollack, "Anthropogenic albedo changes and the earth's climate," Science, vol. 206, issue. 4425, pp. 1363-1368, December 1979.

[31] N. Fernández, J. M. Paruelo, and M. Delibes, "Ecosystem functioning of protected and altered Mediterranean environments: A remote sensing classification in Doñana, Spain," Remote Sensing of Environment, vol. 114, issue 1, pp. 211-220, January 2010.

[32] C. J. Robinove, P. S. Chavez Jr., D. Gehring, and R. Holmgren, "Arid land monitoring using landsat albedo difference images," Remote Sensing of Environment, vol. 11, pp. 133-156, 1981.

[33] P. T. Tueller, "Remote sensing science applications in arid environments," Remote Sensing of Environment, vol. 23, issue 2, pp. 143-154, November 1987.

[34] W. H. Wischmeier and D. D. Smith, "Predicting rainfall erosion losses-a guide to conservation planning: agriculture handbook," Washington USDA, 1978.

[35] T. Laosuwan, S. Pattanasethanon, and W. Sa-Ngiamvibool. (January 2013). Using GIS, RS for soil erosion mapping. Geospatial World Weekly. [Online]. Available: http://www.geospatialworld.net/paper/application/ArticleView.aspx?a id $=30407$
[36] H. M. J. Arnoldus, "Methodology used to determine the maximum potential average annual soil loss due to sheet and rill erosion in Morocco," FAO/UNEP Expert Consultation on Assessing Soil Degradation, FAO: Rome, Italy, 1977, pp. 39-48.

[37] K. G. Renard and J. R. Freimund, "Using monthly precipitation data to estimate the r-factor in the revised USLE," Journal of Hydrology, vol. 157, issues 1-4, pp. 287-306, May 1994.

[38] T. Liu, Z. Liu, and W. Sun, "Research of cover and management factor in the model of the revised universal soil loss equation of black earth erosion in northeastern part of china," Applied Mechanics and Materials, vol. 209-211, pp. 1190-1193, October 2012.

[39] J. M. Van der Knijff, R. J. A. Jones, and L. Montanarella, "Soil Erosion Risk: Assessment in Italy," European Soil Bureau, JRC, Space Applications Institute, pp. 17-20, 1999.

[40] E. De Martonne, "Une nouvelle function climatologique: l'indice de aridité," Météor, vol. 2, pp. 449-458, 1926.

[41] J. Carilla, H. R. Grau, L. Paolini, and M. Morales, "Lake fluctuations, plant productivity, and long-term variability in high-elevation tropical an dean ecosystems," Arctic, Antarctic, and Alpine Research, vol. 45, issue 2, pp. 179-189, May 2013.

[42] K. N. Tiwari, D. K. Paul, and M. K. Gontia, "Characterisation of meteorological drought," Hydrology Journal, vol. 30, issue 1\&2, pp. 15-28, March - June 2007

[43] S. B. Green, "How many subjects does it take to do a regression analysis?" Multivariate Behavioral Research, vol. 26, issue 3, pp. 499-510, 1991

[44] J. Noble. (2012). Lecture: Relationship between Two Variables: Correlation, Covariance and R-squared. University of Southampton. [Online]. http://users.ecs.soton.ac.uk/jn2/teaching/correlations.pdf

Available:

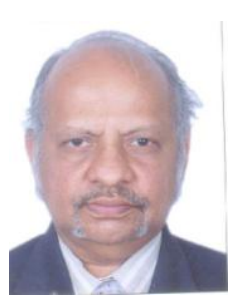

M. V. Khire was born in Mumbai, Maharashtra, India on September 23, 1951. He is basically a civil engineer, with B.E. in 1974 from University of Bombay and has acquired his M.Tech. in 1977 and $\mathrm{Ph} . \mathrm{D}$. in 1988 from Indian Institute of Technology Bombay. His doctoral work was on 'Spectral Behaviour of Soils with Special Reference to Laterites on Hilly Terrain'.

$\mathrm{He}$ is an associate professor in 'Centre of Studies in Resources Engineering, Indian Institute of Technology, Bombay'. He joined the Centre in 1977 and since then he is working on Applications of Remote Sensing in Terrain Evaluation and Land use / Land cover Mapping required in various type of civil engineering projects. In CSRE, he has worked on 13 research projects as Principal Investigator and on 15 research projects as Co-PI. All these projects are on Applications of Remote Sensing in Terrain Evaluation for various purposes and are sponsored by various Government of India organizations such as Department of Science and Technology, Defence Research and Development Organisation, Department of Space, National Wasteland Development Board, Ministry of Environment and Forests etc. He has also worked on about 20 consultancy projects in geotechnical investigations and in Terrain Evaluation and LU/LC Mapping using Remote Sensing data, for various organizations such as City and Industrial Development Corporation, Konkan Railway Corporation Limited, Koyna Dam Authority, Bharat Petroleum Corporation Limited etc. His work has been presented through about 35 papers and 50 reports. He has convened 15 short term training courses and 3 long term courses for transfer of technology to particularly in-service scientists and engineers.

Prof. M. V. Khire is a life member of Indian Society of Remote Sensing and Indian Society of Geomatics 